\title{
DERIVATIONAL AFFIXES INTONTEMBOAN LANGUAGE
}

\section{Rinny Rorimpandey}

Universitas Negeri Manado (UNIMA) Sulawesi Utara, Indonesia

Email: rorimpandeyrinny@unima.ac.id

\begin{abstract}
The Tontemboan language is one of the regional languages in Minahasa. This language has two dialects namely Makela'I and Matana'i. The purpose of this writing is to describe one side of the morphological process of Tontemboan language, in particular, Makela'I dialect, which is focused on Derivational affixes in Tontemboan language, their arrangement, and combination with other morphemes to form words, and their function. In conducting this research, the writer uses the qualitative method. In collecting data she used several techniques: Observation, interviewing, and analyzing written texts were used to collect and analyze data. The informants are choosing according to certain criteria, they came from the Motoling Barat Region. The result is there are 6 Derivational prefixes, those are: prefix $\{$ ma- $\}$ paka -$\},\{$ ta -$\},\{\mathrm{ka}-\},\{$ pa -$\}\{$ maka -$\}, 2$ Derivational infixes, they are:Infix $\{-$ in -$\}$, Infix $\{-$ um -$\}, 1$ Derivational suffix $\{-$ an $\}, 4$ Derivational Confixes they are: $\{$ ka-an $\},\{$ pa-an $\},\{$ maka - em $\},\{$ maka - em $\}$, \{um-em\}. Derivational affixes change the word class of their base form. It is expected that the result of this writing could be a contribution to the teaching of language, in particular the Tontemboan language.
\end{abstract}

Keywords: derivational; affixes; tontemboan

\section{Pendahuluan}

Language is the most important thing in human life and cannot be separated from human life from morning to night. People cannot convey something to others, cannot communicate if they do not use language. In all activities throughout the day, language is used as a medium of interaction. In line with that, there are two definitions of language expressed by Keraf in (Susanti, 2015), namely: First, language as a means of communication between community members in the form of sound symbols produced by human speech tools. Second, are: Language is a communication system that uses vowel symbols (speech sounds) that are arbitrary. This is the same as what (Wibowo \& Stockton, 2001) says. Language is a system of sound symbols that are meaningful and qualified (produced through vapor) that are arbitrary and conventional, which is used as a communication tool by a group of people to give birth to feelings and thoughts.

Every country in the world has its language. For example, the Indonesian nation has a National Language, namely Indonesian, as the official language of the state, the

$\begin{array}{ll}\text { How to cite: } & \text { Rorimpandey, Rinny (2021) Derivational Affixes Intontemboan Language. Syntax Literate: Jurnal } \\ & \text { Ilmiah Indonesia. 6(7). http://dx.doi.org/10.36418/ syntax-literate.v6i7.3592 } \\ \text { E-ISSN: } & \text { 2548-1398 } \\ \text { Published by: } & \text { Ridwan Institute }\end{array}$


language of instruction for education, a means of transportation at the national level, and a means of developing culture, science, and technology.

In Indonesia, apart from having an official language, around 718 regional languages or mother tongues are identified Indonesia. Because there are various kinds of ethnicity, each sufficiency has a mother tongue, which is what characterizes diversity. Mother tongue is the language that a person has learned or used since he was a child and is the basis and means of communication and understanding of his environment. The mother tongue is identified with the local language.

More and more mother tongues are indicated, but it is undeniable that many mother tongues are threatened with extinction because the number of speakers is decreasing. Some things cause the decline in mother-tongue users, including the entry of globalization of technology and information technology in rural areas, urging the younger generation to choose the language they prefer in communicating with their friends, namely slang which is trendy and popular and is considered cool. Even when some young people use their mother tongue, it is considered that they are old, hick and outdated. Another thing that makes mother tongue threatening is that parents are not used or taught to their children, and it is used less and less in daily activities resulting in loss of social or communicative function.

The extinction of local languages has a significant impact on the sustainability of regional culture. Nowadays, local languages are increasingly being spoken and used in foreign activities. Therefore there needs to be a movement from all communities in preserving regional languages, including researching, publishing books or magazines using local languages, every family needs to use local languages in daily conversations, and every event and include regional languages as part of local content. in school. This research is an effort to preserve local languages. This is expected to contribute to national culture so that future generations can enjoy it.

Tontemboan language (TL) is one of the regional languages or mother tongue in North Sulawesi by the Tontemboan ethnicity. The Tontemboan ethnicity itself is one of the ethnic groups in Minahasa. TL is one of the regional languages in Indonesia which is still actively used by the people who use it in daily communication. This language is a language that has the widest area and uses the largest number of regional languages than other languages in Minahasa. TL has two dialects, namely Matana'I and Makela'I, each of which has its region.

1. The Matana'I dialect covers the Sonder and Kawangkoan regions.

2. The Makela'I dialect covers the Tompaso, Langowan, Rumoong Bawah, Amurang, Motoling, and Tompaso Baru areas.

The difference as well as variants of these two dialects occurs in the consonants. This can be clearly seen in the following example:

\begin{tabular}{lll} 
Makela'I & \multicolumn{2}{c}{ Matana'i } \\
/welen/ & /weren/ & 'eyes' \\
/se'da/ & /sera/ & 'fish'
\end{tabular}




$\begin{array}{ccc}\text { /useb/ } & \text { /usew/ } & \text { 'plan' } \\ \text { /cua/ } & \text { /kua/ } & \text { 'say' }\end{array}$

Although there are differences in pronunciation of the two dialects, it does not necessarily bring about difficulties and undesirable excesses but the condition of using this language has decreased. Formerly, the language was still actively used in people's daily intercourse both by families and the younger people. Communication among families, parents, and children was done using this language. Moreover, informal meetings sermons, meetings and speeches were performed by using this language. Nowadays, most of elderly people speak the language but only a few of the younger can use it in daily communication. Informal meetings the language is rarely used. This is caused by the potential use of the Manado Malay and Bahasa Indonesia and also foreign languages. When the language is rarely used or is not spoken anymore, the existence of this language may be extinct. It might happen that the coming generation will not speak it anymore.

This research is one of the efforts to develop the local languages. It is hoped that it will give a contribution to the national culture so that it can be enjoyed by the coming generation. And various studies have been carried out on TL, including "Noun Derivation Of The Typical Minahasa Food And Beverage Names" by (Pamantung, n.d.) The writer will take a part in maintaining this language by conducting research. "Suffixes In English and Tontemboan Language (A Contrastive Analysis)" by (Tenda, 2015), and "Tontemboan Affixes Notes In Teaching English Tenses" By (Kumayas, 2021). On this occasion the writer is interested in analyzing the TL, she focuses on the derivational affixes in TL. Derivational affixes are to add an affix to the root word and form a new word. The new word or derived word is usually different from the original word class.

A piece of writing must have a certain purpose and target (Maru, Nur, \& Lengkoan, 2020) and (Maru, 2013). The aims to be attained in this writing are: to describe the derivational affixes in the makelei dialect of TL, and to analyze the function and the meaning revealed by derivational affixes in the morphological process. Besides participating in the effort of surviving and maintaining the TL as a valuable heritage in supporting the Bahasa Indonesia as the national language.

In this study, the authors describe and analyze the derivational affixes consisting of, prefix, infix, suffix, and confix, especially the Makele'i dialect. The author tries to describe the derivation of affixes in the TL used by the Motoling Barat community in the Makele'i dialect. For example, seda 'fish' is attached to prefix $\{$ ta- $\}$ becomes tangseda 'like to eat fish'. The prefix $\{$ ta- $\}$ can be attached to a noun, to expresses a hobby or habitual action. The word class changes to an adjective. This example shows that tangseda as an adjective undergoes a derivational process from 'fish' which is a noun. So this way can make it easier for the TL to be understood and understood clearly, especially the use of derivational affixes. 
As a contribution to the morphology of the Tontemboan language, especially in derivational affixes, the writer researched the Tontemboan language, especially in the people of Raanan Baru Village, Motoling Barat District, with the Makele'i dialect.

1. Morphology

Abdul (Chaer, 2003) explained that etymologically the word morphology comes from the word morph which means 'form' and the word logy which means 'science'. So literally the word morphology can be interpreted as 'the science of forms'. While according to (Mulyana, 2000) argued that the term 'morphology' is derived from English morphology, which means the branch of linguistics that studies the grammatical arrangement or parts of words. In the past, this science was better known as morphemics, namely the study of morphemes. However, along with the development and dynamics of language, the term that became more popular was morphology. (Manaf, Juita, \& Sari, 2018) states that morphology is a branch of linguistics that identifies the basic units of language as grammatical units, while (Siahaan, 2012) defines morphology as a branch of linguistics that studies the structure and forms of words.

So morphology is part of linguistics that analyzes the intricacies of the word. The process of forming words can affect changes in the form of words and also on the class and meaning of words. Morphology is inseparable from the name morpheme and word.

2. Morpheme

Based on (Lieber, 2004) said that "Morpheme is the meaningful units that are used to form words." Morphemes are the smallest units of language that have meaning in one utterance. According to (Payne \& Almansour, 2014) Morpheme is the smallest meaningful unit in the grammar of a language. This is the same as stated by (Adhicahya, 2015) morpheme is the smallest element that individually contains the meaning in the utterance of a language. (Yule, 2016) confirmed that the definition of a morpheme is "a minimal unit of meaning or grammatical function. Units of grammatical function include forms used to indicate past tense or plural. Example word reopened, consist of three morphemes, they are: open is one minimal unit of meaning, re-(meaning 'again'), and -ed as a minimal unit of grammatical function (indicating past tense).So the morpheme is the smallest unit in a language and has meaning and is part of or is a form of words in a language. A morpheme can be divided into 2 parts, namely:

a. Morpheme free.

Based on (Yule, 2016) said that 'Free morpheme that can stand by themselves as single words'.

The free morpheme is a morpheme that can immediately form a sentence or a morpheme that can stand alone without having to be attached to other morphemes, for example, boy, open, walk, play, sing, drink.

Free morpheme is divided into two parts, namely: 
1) Lexical morpheme or known as open class word can be in the form of Noun, verb, and adjective. For example: go, yellow, student.

2) Functional morpheme, also known as Close class word, or like Pronouns, Prepositions, etc. Example only, that, so, in, you, them, because.

b. Morphemes are bound

Based on (Yule, 2016) Bound morphemes, which are those forms that cannot normally stand alone and are typically attached to another for. According to (Lieber, 2004), "Bound Morpheme is a morpheme that cannot stand alone". This means that a bound morpheme is a morpheme that cannot directly build a sentence, but is always tied to other morphemes. For example an affix. dis-, -s, ly. bound is unlike the free morpheme, but it is glued to another morpheme.

The bound morpheme is divided into two parts, namely:

1) Derivational morpheme: according to (Ingguoe, 2015) says, it is a construction that has a different distribution from its base. Likewise with (Azis, 2016), said that Derivational is a morphological process because of the affixation which causes the formation of various formations provided that the form changes the word class of the root word. (Yule, 2016) said that derivational morpheme, these bound morphemes to make new words or to make words of a different grammatical category from the stem. For example the addition of derivational morpheme -ness changes the adjective good to the noun goodness. So derivational morpheme is to change the class of words from noun, verb, adjective and also change the meaning, it can be in the form of a suffix or prefix.

2) The second set of bound morphemes are called Inflectional morpheme. These are not used to produce new words in the language, but rather to indicate aspects of the grammatical function of a word (Yule, 2016). Thus Inflectional morpheme is a morpheme that does not produce a new word but identifies singular or plural, past tense or not, comparative or superlative.

3. Word

Based on (Mezrag, 2013) said that a Word is a free morpheme or a combination of morphemes that together form a basic segment of speech. Meanwhile, (Untung, Kushartanti, \& Multamia, 2007) said that words are the smallest independent units, or in other words, every independent unit is a word. A word is a unit of language consisting of a single morpheme or a group of morphemes (Halikowski Smith, 2016). So the word is the smallest unit of sentences that have meaning or ideas. A free morpheme can be a word and a word can be a single form or consist of one grammatical unit and can also be a complex form or consist of several grammatical units. Words are divided into 8 types, namely:

a. Nouns or nouns are used for the names of people, things, animals, places, and ideas or concepts. The noun itself can be further divided into various types, such as countable, uncountable / mass, common, proper, concrete, abstract, and collective noun. 
b. A pronoun is a word used to replace a noun. There are 8 types of pronouns, namely personal, demonstrative, interrogative, indefinite, possessive, reciprocal, relative, reflexive, and intensive pronoun.

c. Verb is a verb that is used to denote an action or a state. Verbs can be divided into several types, such as action verbs and linking verbs.

d. Adjective is an adjective that is used to provide information on a noun or pronoun.

e. Adverbs can also be grouped into several types, such as manner, degree, frequency, place, and time.

f. The preposition function is to show the relationship between nouns and other words in a sentence.

g. Conjunctions are used to connect two words, phrases, clauses to sentences. There are 3 types of conjunction, namely coordinating, subordinating, and correlative conjunctions.

h. Interjection is a type of word that is usually used to express emotions.

4. Affixation

Among the morphemic processes, the most important thing is affixation, namely, affix affixation. (Sunardi, 2012), "Affix is a morpheme which only occurs when attached to some other morpheme or morphemes such as a root or stem or base. Obviously, by definition affixes are terms are bound morpheme ". (Siahaan, 2012) Affixation is the affixing of affixes to a form, both singular and complex forms to form words. The process of adding prefix, infix, suffix, and confix. An affix concern with a segmental unit a word which is not free morpheme but can attach to other morphemes in forming a word, with or without a change of a word class,

a. Prefix

"The prefix is affix attached before a root or stem or base like re-, un-, and in-, for example, re-make, un-happy, in-decent", According to (Sunardi, 2012). So Prefix is the process of forming words by adding a prefix to the morpheme or the appendix on the left. This prefix turns the morpheme into a complex word.

Below are examples of prefixes in Indonesian:

$\begin{array}{lll}\text { Base } & \text { prefixes } & \\ \text { Main } & \text { ber- } & \text { bermain } \\ \text { Masak } & \text { me- } & \text { memasak } \\ \text { Tulis } & \text { di- } & \text { ditulis } \\ \text { Tawa } & \text { ter- } & \text { tertawa } \\ \text { Marah } & \text { pen- } & \text { pemarah }\end{array}$

Examples of prefixes in English:

Base prefixes

Play re- replay

Understand mis- misunderstanding

Agree dis- disagree 
$\begin{array}{lll}\text { Election } & \text { pre- } & \text { preelection } \\ \text { Possible } & \text { im- } & \text { impossible }\end{array}$

Examples of prefixes in Tontemboan:

$\begin{array}{lll}\text { Base } & \text { prefixes } & \text { kata berprefiks. } \\ \text { Siwo 'masak' } & \text { ma- } & \text { masiwo 'memasak' } \\ \text { Rua 'dua' } & \text { ka- } & \text { karua 'kedua' } \\ \text { Wali 'bawa' } & \text { i- } & \text { iwali 'dibawa' } \\ \text { Wale 'rumah' } & \text { maka- } & \text { makawale 'pemilik rumah' }\end{array}$

Before being prefixed, the morpheme is single (each morpheme is always single), but after being prefixed the shape becomes complex.

b. Infixes

Those bound morphemes which are inserted within the base are called infixes (Effendy, 2011). Infixation is the process of forming words through the addition of an infix or insertion to the morpheme or affix by insertion in the base. This fixation turns the morpheme into complex words.

Infixation in Indonesian, as follows:

$\begin{array}{lcl}\text { base } & \text { infixes } & \\ \text { tunjuk } & \text {-el- } & \text { telunjuk } \\ \text { gunung } & \text {-em- } & \text { gemunung } \\ \text { gigi } & \text {-er- } & \text { gerigi } \\ \text { kerja } & \text {-in- } & \text { kinerja }\end{array}$

Infixes in Tontemboan are illusustrated below:

Base infixes

Kais 'sapu' -in-

kinais 'disapu' /

'dibersikan'

Tawoy 'kerja' - -um- tumawoy 'akan bekerja'

Pokol 'potong' -in- pinokol 'telah dipotong'

Siwo 'masak' - -um- sumiwo 'akan memasak'

c. Suffixes

Suffixes are the bound morphemes that occur, after a base (Ahmed \& Isma'eel, 2011). So, suffixation is the process of forming words by adding a suffix to the morpheme or the appendix to the right of the base.

The process of suffixes in English is as follows:

$\begin{array}{lll}\text { Base } & \text { Suffixes } & \\ \text { Govern } & \text {-ment } & \text { government } \\ \text { Art } & \text {-ist } & \text { artist }\end{array}$




$\begin{array}{lll}\text { Play } & \text {-ed } & \text { played } \\ \text { Narrow } & \text {-er } & \text { narrower } \\ \text { Comfort } & \text {-able } & \text { comfortable } \\ \text { Sing } & \text {-ing } & \text { singing } \\ \text { Read } & -s & \text { reads }\end{array}$

The process of suffixes in Indonesia is as follows:

$\begin{array}{lll}\text { Base } & \text { Suffixes } & \\ \text { Baca } & - \text { kan } & \text { bacakan } \\ \text { Seni } & - \text { man } & \text { seniman } \\ \text { Dapat } & -\mathrm{i} & \text { duduki } \\ \text { Makan } & - \text { an } & \text { makanan }\end{array}$

The process of suffixes in Tontembon as follows:

$\begin{array}{lll}\text { Base } & \text { Suffixes } & \\ \text { Indo 'ambil' } & \text {-nii } & \text { indonii 'ambilkan' } \\ \text { Engket 'nyala' } & \text {-an } & \text { engketan 'nyalai' }\end{array}$

d. Confixes

Confixes are the combination of prefixes and suffixes or more segments of affixes attached to a base (Effendy, 2011). Confirmation is a combination of affixes or a combination of prefix and affix or infix or which is applied for a part on the left of the base and apart on the right.

The process of Confixes in Indonesia is as follows:

$\begin{array}{lll}\text { Base } & \text { confixes } & \\ \text { indah } & \text { ke-an } & \text { keindahan } \\ \text { gunung } & \text { pe-an } & \text { pegunungan } \\ \text { nyanyi } & \text { me-kan } & \text { menyanyikan }\end{array}$

The process of confixes in Tontemboan is as follows:

$\begin{array}{llll}\text { Base } & & \text { confixes } & \\ \text { Sia } & \text { 'kaya' } & \text { ka-an } & \text { kasiaan 'kekayaan' } \\ \text { Siwo } & \text { 'masak' } & \text { pa-an } & \text { pasiwoan 'tempat masa } \\ \text { Teles } & \text { 'beli' } & \text {-um-em } & \text { tumelesem 'telah dibeli' }\end{array}$

\section{Methods}

To conduct this research, a qualitative method was used for analyzing the data. The data that has been taken was in the form of words. Bogdan and Taylor stated that "Qualitative methodology is research procedure that produces descriptive data in the form of written and spoken words from people and observed behavior". Based on that 
statement, the data in this research was not dealing with numbers, diagrams, or formulas, but in the forms of words or quotations.

In carrying out the data, the researcher used three techniques of data collection, namely observation, interview and recording techniques. Observation is kind of technique used by the researcher to observe the language used by Motoling Barat local people. Interview technique is a technique in which the researcher asks questions to the local people and recording technique where the researcher records the informants' responses.

In this research, the researcher herself was the main instrument in obtaining and analyzing the data. To support this study, the researcher used tape recorder to record the use of spoken language by the local people and also used manuscripts that written in TL.

The procedures of data analysis were based on Miles and Huberman's theory (1994), there are data reduction, data display, and data verification/ conclusion. 1). Data reduction refers to the process of selecting and transforming the data that appear in a record or manuscript. 2). Data display, by organized, compressed assembly of information that permits conclusion drawing and action. 3) Conclusion drawing and verification, in this step, it concluded as the result of the study. The researcher will identify the word and the affixes attached in Tontemboan language spoken by the local people in Motoling Barat. Next, grouping the affixes, giving examples in sentences, and then drawing the result.

\section{Result and Discussion}

Derivational Affixes are affixes that form words, namely word-forming affixes that change the class of words. Derivation formatter affixes include:

1. Derivational Prefixes.

There are 6 kinds of derivational prefixes in the Tontemboan language, namely

a. The prefix ma- combined with the adjective will change the word class to become a verb indicating causative notion.

\begin{tabular}{|c|c|c|c|c|}
\hline Prefix & base & & verb & \\
\hline ma- & wuling & 'black' & mawuling & 'to blacken' \\
\hline ma- & wola & 'blind' & mawola & 'to blind' \\
\hline ma- & worung & 'thin' & maworung & 'to thin' \\
\hline ma- & wangker & 'large' & mawangker & 'to enlarge' \\
\hline ma- & lambot & 'long' & malambot & 'to lengthen' \\
\hline ma- & keli & 'much' & makeli & 'become much' \\
\hline ma- & kolek & 'short' & makolek & 'to shorten' \\
\hline ma- & welad & 'wide' & mawelad & 'to widen' \\
\hline
\end{tabular}

b. Prefix paka-

When prefix paka- is attached to numerals, the notion expressed is the situation of a base meaning 'times'. 


\begin{tabular}{|c|c|c|c|c|}
\hline Prefix & base & & verb & \\
\hline paka- & rua & 'two' & pakarua & 'two times' \\
\hline paka- & telu & 'three' & pakatelu & 'two times' \\
\hline paka- & epat & 'four' & pakaepat & 'four times' \\
\hline paka- & siow & 'nine' & pakasiow & 'nine times' \\
\hline paka- & pitu & 'seven' & pakapitu & 'seven times \\
\hline
\end{tabular}

c. Prefix ta-

The prefix ta- can be attached to a verb and a noun. This prefix takes the form of tang when it is attached to a base beginning with the velar stop /K/, /t/, /s/, and it takes the form of being when it is attached to a base beginning with the consonants $/ \mathrm{b} /$, and $/ \mathrm{p} /$. When the prefix is attached to verbs, it changes the verbs to adjectives expressing 'hobby' or 'habit'.

The following is the prefix attached to verbal bases:

\begin{tabular}{lllll} 
Prefix & base & \multicolumn{3}{c}{ adjective } \\
ta- & ame & 'cry' & tame & 'like cry baby' \\
ta- & waya & 'walk' & tame & 'like walking' \\
ta- & elep & 'drink' & tame & 'like drinking' \\
ta- & kantar & 'sing' & tame & 'like singing'
\end{tabular}

The prefix ta- can also be attached to a noun and expresses a hobby or habitual action. The word class changes to an adjective. This is shown below:

\begin{tabular}{|c|c|c|c|c|}
\hline Prefix & base & & adjective & \\
\hline ta- & kawok & 'mice' & tangkawok & 'like to eat mice' \\
\hline ta- & seda & 'fish' & tangseda & 'like to eat fish' \\
\hline ta- & tuama & 'boy' & tangtuama & 'like to change partner' \\
\hline ta- & kesol & 'frog' & tangkesol & 'like to eat frog' \\
\hline ta- & ame & 'cry' & tame & 'like cry baby' \\
\hline
\end{tabular}

The form ta- becomes tam- when the prefix is attached to a base beginning with the consonants $/ \mathrm{b} /$ and $/ \mathrm{p} /$.

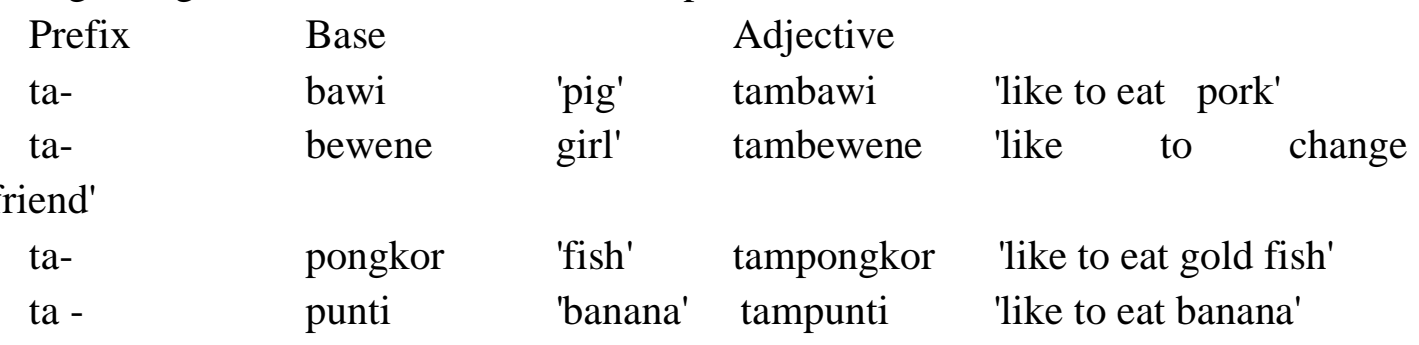

d. Prefix 'ka-'

The prefix ka- can be attached to nouns and numerals. When it is attached to nouns it expresses the notion of 'similarity as indicated by the base. 
Rinny Rorimpandey

\begin{tabular}{lllll} 
Prefix & Base & \multicolumn{3}{c}{ Verb } \\
ka- & ngaran & 'name' & kangaran & 'have same name' \\
ka- & papa & 'father' & kapapa & 'have same father' \\
ka- & namo & 'face' & kanamo & 'have similar face' \\
ka- & sicola & 'school' & kasicola & 'have same school'
\end{tabular}

This prefix has the ability to be attached to numerals and functions to express ordinality.

$\begin{array}{lllll}\text { Prefix } & \text { Base } & & \text { Ordinal } & \\ \text { ka- } & \text { rua } & \text { 'two' } & \text { karua } & \text { 'second' } \\ \text { ka- } & \text { esa } & \text { 'one' } & \text { katare } & \text { 'first' } \\ \text { ka- } & \text { telu } & \text { 'three' } & \text { katelu } & \text { 'third' } \\ \text { ka- } & \text { epat } & \text { 'four' } & \text { kaepat } & \text { 'fourth' } \\ \text { ka- } & \text { lima } & \text { 'five' } & \text { kalima } & \text { 'fifth' } \\ \text { ka- } & \text { pitu } & \text { 'seven' } & \text { kapitu } & \text { 'seventh' } \\ \text { ka } & \text { siow } & \text { 'nine' } & \text { kasiow } & \text { 'nineth' }\end{array}$

e. Prefix 'pa-'

The prefix pa- can be attached to a verb and it has the function of forming a noun. In this strategy, it denotes 'tool'. The following words show this process:

\begin{tabular}{|c|c|c|c|c|}
\hline $\begin{array}{l}\text { Prefix } \\
\text { pa- }\end{array}$ & $\begin{array}{l}\text { base } \\
\text { teles }\end{array}$ & 'buy' & $\begin{array}{c}\text { Noun } \\
\text { pateles }\end{array}$ & 'a tool which is used for buving' \\
\hline$a-$ & wuas & 'wash' & pawuas & 'a tool which is used for washing' \\
\hline pa- & pokol & 'cut' & papokol & 'a tool which is used for cutting' \\
\hline pa- & keis & 'sweep' & pakeis & 'a tool which is used for \\
\hline$a-$ & baca & 'read' & pabaca & 'a tool which is used for reading' \\
\hline & kocot & 'comb' & pakocot & 'a tool which is used for \\
\hline & siwo & 'cook' & pasiwo & 'a tool which is used for cooking' \\
\hline
\end{tabular}

f. Prefix 'maka-'

When the prefix maka- is attached to a noun, it changes the noun into a verb to express 'ownership'.

\begin{tabular}{|c|c|c|c|c|}
\hline Prefix & base & & Verb & \\
\hline maka- & oto & 'car' & makaoto & 'own a car' \\
\hline maka- & toyaang & 'child' & makatoyaang & 'own a child' \\
\hline maka- & cingke & 'clove' & makacingke & 'own cloves' \\
\hline maka- & ta' be & 'field' & makata'be & 'own a \\
\hline maka- & wale & 'house' & makawale & 'own a house' \\
\hline maka- & TV & 'TV' & makatv & 'own a TV' \\
\hline
\end{tabular}


maka- sapi 'cow' makasapi 'own a cow'

Besides, the prefix maka- can be attached to an adjective, and the word class is also changed into a verb. It indicates 'causative' with the meaning of 'becoming' or 'turning'. The following words show this process.

$\begin{array}{lllll}\text { Prefix } & \text { base } & & \text { Verb } \\ \text { maka- } & \text { lengey } & \text { 'poor' } & \text { maklengey } & \text { 'to become poor' } \\ \text { maka- } & \text { rindang } & \text { 'red' } & \text { makarindang } & \text { 'to redden' } \\ \text { maka- } & \text { worung } & \text { 'thin' } & \text { makaworung } & \text { 'to thin' } \\ \text { maka- } & \text { biongo } & \text { 'stupid' } & \text { makabiongo } & \text { 'to stupify' } \\ \text { maka- } & \text { wangker } & \text { 'large' } & \text { makawangker } & \text { 'to enlarge' } \\ \text { maka- } & \text { wobas } & \text { 'young' } & \text { makawobas } & \text { 'to turn young' } \\ \text { maka- } & \text { rames } & \text { 'wet' } & \text { makarames } & \text { 'to wet' }\end{array}$

Infixes are those bound morphemes that are interested within a base. The Tontemboan language has two kinds of infixes: - in - and - um -.

g. Infix ' - in - '

The infix -in- can be inserted within an adjective and it will form a verb. It still served as a verb formation to indicate past aspect with a passive meaning. The process is shown below:

\begin{tabular}{lllll} 
Infix & base & \multicolumn{3}{c}{ Verb } \\
-in- & tombal & 'sweet' & tinombal & 'be sweetened' \\
-in- & kolek & 'short' & kinolek & 'be shortened' \\
-in- & rindang & 'red' & rinindang & 'be reddened' \\
-in- & wangker & 'large' & winangker & 'be enlarge'
\end{tabular}

h. Infix '-um-'

This affix can be inserted within an adjective. In this case it has a function of forming a verb that indicates causation. The following words show this process:

\begin{tabular}{|c|c|c|c|c|}
\hline Infix & Base & & Verb & \\
\hline -um- & tayang & 'far' & tumayang & 'to further' \\
\hline -um- & kemel & 'fat' & kumemel & 'to fat' \\
\hline -um- & rangka & 'high' & rumangka & 'to heighten' \\
\hline -um- & tombal & 'sweet' & tumombal & 'to sweeten' \\
\hline -um- & kulo & 'white' & kumulo & 'to whiten' \\
\hline -um- & repet & 'fast' & rumepet & 'to fasten' \\
\hline n- & lengey & 'poor' & lumengey & 'to become poor' \\
\hline
\end{tabular}


Suffixes are bound morphemes that are attached after a base. In the Tontemboan language there are several suffixes: -an, -nii. Each of these suffixes is discussed below.

i. Suffix '- an'

The suffix can be attached to adjective. It will form imperative or express a request or an order to do something as shown below:

\begin{tabular}{lllll} 
Suffix & Base & \multicolumn{3}{c}{ Verb } \\
-an & lambot & 'long' & lambotan & 'lengthen' \\
-an & tombal & 'sweet' & tombalan & 'sweeten' \\
-an & render & 'angry' & renderan & 'scold' \\
-an & kemel & 'fat' & kemelan & 'fat' \\
-an & tayang & 'far' & tanyangan & 'further' \\
-an & repet & 'fast' & repetan & 'fast' \\
-an & worung & 'thin' & worungan & 'thin'
\end{tabular}

A confix consist of two or more affixes combines and put together with a base (Effendy, 2011). It is a combination of two or more affixes that flank a base. The confixes in the Tontemboan language are ka-an, pa-an, maka-em, um-em, -inem, men-an, ma-pa, maka-pe. Furthermore, the confixes are discussed below.

j. Confix 'ka-an'

The confix ka-an is derivational. It derives a new word when it is attached to an adjective to create a noun.

\begin{tabular}{lllll} 
Confix & Base & \multicolumn{4}{c}{ Noun } \\
ka-an & sia & 'wealthy' & kasiaan & 'wealth' \\
ka-an & kemel & 'fat' & kakemelan & 'over weight' \\
ka-an & repet & 'speedy' & karepetan & "speed' \\
ka-an & tayang & 'far' & katayangan & 'distance' \\
ka-an & tombal & 'sweet' & katombalan & 'sweetness' \\
ka-an & lengey & 'poor' & kalengeyan & 'poverty' \\
ka-an & kulo & 'white' & kakuloan & 'whiteness'
\end{tabular}

k. Confix 'pa-an'

The confix pa-an is also derivational. It is only attached to a verb base. When it is attached to a verb it creates a noun indicating a place of the base. This is shown below:

\begin{tabular}{lllll} 
Confix & Base & \multicolumn{4}{c}{ Noun } \\
pa-an & tekel & 'sleep' & patekelan & 'place for sleeping' \\
pa-an & siwo & 'cook' & pasiwoan & 'place for cooking' \\
pa-an & wuas & 'wash' & pawuasan & 'place for washing' \\
pa-an & kantar & 'sing' & pakantaran & 'place for singing' \\
pa-an & tawoy & 'work' & patawoyan & 'place for working'
\end{tabular}




$\begin{array}{lllll}\text { pa-an } & \text { sere } & \text { 'see' } & \text { paserean } & \text { 'place for seeing' } \\ \text { pa-an } & \text { keis } & \text { 'sweep' } & \text { pakeisan } & \text { 'place for sweeping' } \\ \text { pa-an } & \text { tangka } & \text { 'catch' } & \text { patangkaan } & \text { 'place for catching' }\end{array}$

1. Confix 'maka-em'

The confix maka-em can be attached to a verb, an adjective, and a noun. It functions to form a verb when it is attached to an adjective or a noun. This process denotes a perfective aspect or an activity that has been done. This process is shown below in which words are grouped according to their bases.

The confix 'maka-em' attached to adjectival bases:

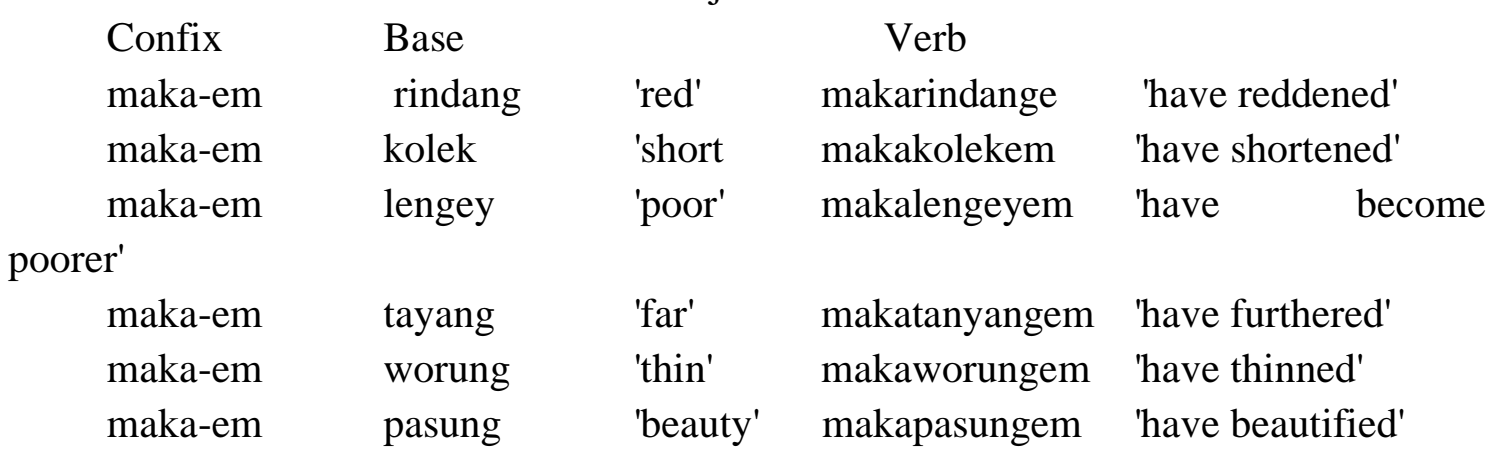

The confix 'maka-em' attached to noun bases:

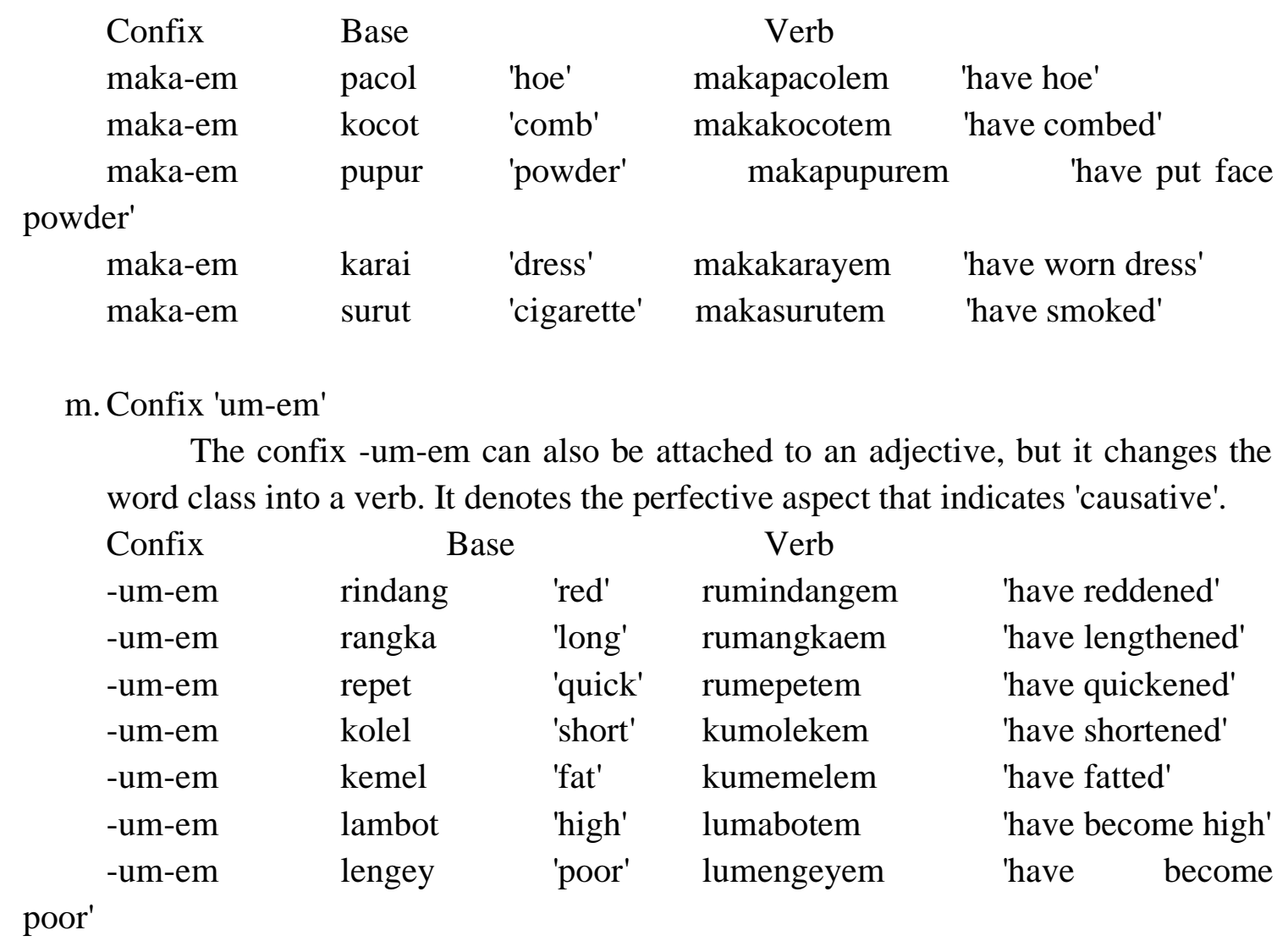


Table 1

Derivational Affixes in Tontemboan Languages

\begin{tabular}{|c|c|c|c|c|}
\hline No & Affixes & Base & New word class & Meaning \\
\hline 1 & $\begin{array}{l}\text { Prefix } \\
\text { ma- }\end{array}$ & $\begin{array}{l}\text { Adjective } \\
\text { wuling } \\
\text { /black/ }\end{array}$ & $\begin{array}{l}\text { Verb } \\
\text { mawuling } \\
\text { /to blacken/ }\end{array}$ & $\begin{array}{l}\text { The word becomes verb indicting } \\
\text { causative notion }\end{array}$ \\
\hline 2 & $\begin{array}{l}\text { Prefix } \\
\text { paka- }\end{array}$ & $\begin{array}{l}\text { Numeral } \\
\text { rua } \\
/ \text { two/ }\end{array}$ & $\begin{array}{c}\text { Verb } \\
\text { pakarua } \\
\text { /two times/ }\end{array}$ & $\begin{array}{l}\text { The notion expressed is the } \\
\text { situation of a base meaning 'times' }\end{array}$ \\
\hline \multirow[t]{2}{*}{3} & $\begin{array}{l}\text { Prefix } \\
\text { Ta- }\end{array}$ & $\begin{array}{l}\text { Verb } \\
\text { ame } \\
\text { /cry/ }\end{array}$ & $\begin{array}{c}\text { Adjective } \\
\text { taame } \\
\text { /like cry baby? }\end{array}$ & Expressing 'hobby' or 'habit' \\
\hline & $\begin{array}{l}\text { Prefix } \\
\text { Ta- }\end{array}$ & $\begin{array}{l}\text { Noun } \\
\text { seda } \\
\text { /fish/ }\end{array}$ & $\begin{array}{l}\text { Adjective } \\
\text { tangseda } \\
\text { /like to eat fish/ }\end{array}$ & $\begin{array}{c}\text { Expresses a hobby or habitual } \\
\text { action }\end{array}$ \\
\hline 4 & $\begin{array}{c}\text { Prefix } \\
\text { Ka- }\end{array}$ & $\begin{array}{l}\text { Noun } \\
\text { Ngaran } \\
\text { /name/ }\end{array}$ & $\begin{array}{c}\text { Verb } \\
\text { Kangaran } \\
\text { /have same name/ }\end{array}$ & $\begin{array}{l}\text { It expresses the notion of } \\
\text { 'similarity' as indicated by the base }\end{array}$ \\
\hline 5 & $\begin{array}{l}\text { Prefix } \\
\text { Pa- }\end{array}$ & $\begin{array}{l}\text { Verb } \\
\text { Pokol } \\
\text { /cut/ }\end{array}$ & $\begin{array}{c}\text { Noun } \\
\text { Papokol } \\
\text { /a tool which is used } \\
\text { for cutting/ }\end{array}$ & It denotes 'tools' \\
\hline 6 & $\begin{array}{l}\text { Prefix } \\
\text { Maka- }\end{array}$ & $\begin{array}{l}\text { Noun } \\
\text { oto } \\
\text { /car/ }\end{array}$ & $\begin{array}{l}\text { Verb } \\
\text { makaoto } \\
\text { /own a car/ }\end{array}$ & To express 'ownership' \\
\hline 7 & $\begin{array}{l}\text { Prefix } \\
\text { Maka- }\end{array}$ & $\begin{array}{l}\text { Adjective } \\
\text { lengey } \\
\text { /poor/ }\end{array}$ & $\begin{array}{c}\text { Verb } \\
\text { makalengey } \\
\text { /to become poor/ }\end{array}$ & $\begin{array}{l}\text { It indicates 'causative' with the } \\
\text { meaning of 'becoming' or } \\
\text { 'turning' }\end{array}$ \\
\hline 8 & $\begin{array}{l}\text { Infix } \\
\text {-in- }\end{array}$ & $\begin{array}{l}\text { Adjective } \\
\text { tombal } \\
\text { /sweet/ }\end{array}$ & $\begin{array}{l}\text { Verb } \\
\text { tinombal } \\
\text { /tinombal/ }\end{array}$ & $\begin{array}{l}\text { It serve as a verb formation to } \\
\text { indicates past aspect with a passive } \\
\text { meaning }\end{array}$ \\
\hline 9 & $\begin{array}{c}\text { Infikx } \\
\text {-um- }\end{array}$ & $\begin{array}{l}\text { Adjective } \\
\text { tayang } \\
\text { /far/ }\end{array}$ & $\begin{array}{l}\text { Verb } \\
\text { /tumayang/ } \\
\text { /to further/ }\end{array}$ & $\begin{array}{l}\text { It has a function of forming a verb } \\
\text { that indicates causation }\end{array}$ \\
\hline 10 & $\begin{array}{l}\text { Suffix } \\
\text {-an }\end{array}$ & $\begin{array}{l}\text { Adjective } \\
\text { lambot } \\
\text { /long/ }\end{array}$ & $\begin{array}{l}\text { Verb } \\
\text { tambotan } \\
\text { /lengthen/ }\end{array}$ & $\begin{array}{l}\text { It will form imperative or express } \\
\text { a request or order to do something }\end{array}$ \\
\hline 11 & $\begin{array}{l}\text { Confix } \\
\mathrm{Ka}-\text { an }\end{array}$ & $\begin{array}{l}\text { Adjective } \\
\text { sia } \\
\text { /wealthy/ }\end{array}$ & $\begin{array}{l}\text { Noun } \\
\text { kasiaan } \\
\text { /wealth/ }\end{array}$ & $\begin{array}{c}\text { Attached to an adjective to create a } \\
\text { noun }\end{array}$ \\
\hline 12 & $\begin{array}{l}\text { Confix } \\
\mathrm{Pa}-\text { an }\end{array}$ & $\begin{array}{l}\text { Verb } \\
\text { tekel } \\
\text { /sleep/ }\end{array}$ & $\begin{array}{c}\text { Noun } \\
\text { patekelan } \\
\text { /place for sleeping/ }\end{array}$ & $\begin{array}{l}\text { Indicating a place relevant to the } \\
\text { meaning of the base }\end{array}$ \\
\hline 13 & $\begin{array}{l}\text { Confix } \\
\text { Maka - } \\
\text { em }\end{array}$ & $\begin{array}{l}\text { Adjective } \\
\text { rindang } \\
\text { /rindang/ }\end{array}$ & $\begin{array}{l}\text { Verb } \\
\text { makarindangem } \\
\text { /have reddened/ }\end{array}$ & $\begin{array}{c}\text { This process denotes perfective } \\
\text { aspect or an activity that has been } \\
\text { done }\end{array}$ \\
\hline 14 & $\begin{array}{l}\text { Confix } \\
\text { Maka - } \\
\text { em }\end{array}$ & $\begin{array}{l}\text { Noun } \\
\text { pacol } \\
\text { /hoe/ }\end{array}$ & $\begin{array}{c}\text { Verb } \\
\text { makapacolem } \\
\text { /have hoe/ }\end{array}$ & \\
\hline 15 & Confix & Adjective & Verb & It denotes perfective aspect that \\
\hline
\end{tabular}




\begin{tabular}{ccccc}
\hline No & Affixes & Base & New word class & Meaning \\
\hline & $\begin{array}{c}\text { um }- \\
\text { em }\end{array}$ & $\begin{array}{c}\text { kemel } \\
\text { /fat/ }\end{array}$ & $\begin{array}{c}\text { kumemelem } \\
\text { /have fatted/ }\end{array}$ & indicates 'causative' \\
& & &
\end{tabular}

\section{Conclusion}

Tontemboan language is one of the local language in the regency of Minahasa of The Province of North Sulawesi. It covers two dialects, namely the Makale'i dialect and Matana'I dialect. The volume of using this language among young generation and the children has decreased. Due to the influence of information technology lately, only parents use this language. And even in formal situations, this language is rarely used. This is due to the use of, slang, Manado Malay, Indonesian, and the use of foreign languages. One of the efforts to cope with this problem is to do research on the language.

Derivational affixes to form words in Tontemboan language occur through processes of prefix, infix, suffix, and confix. The affix form of the Tontemboan language is always attached to the root word, verb, noun, adjective, numeral. And 12 types of derivational affixes are still actively used in the Tontemboan language, consisting of 6 Derivational prefixes, those are:

1. Prefix $\{$ ma- $\}+$ adjective

2. Prefix $\{$ paka -$\}+$ numerals

3. Prefix $\{$ ta -$\}+$ verb

4. Prefix $\{k a-\}+$ noun

5. Prefix $\{\mathrm{pa}-\}+$ verb

6. Prefix $\{$ maka -$\}+$ noun

7. Prefix $\{$ maka -$\}+$ adjective

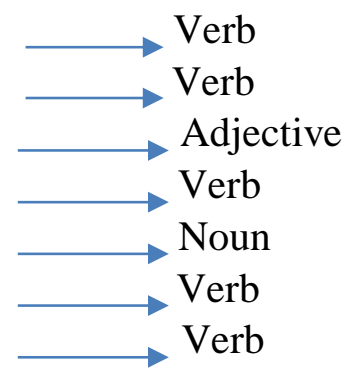

2 Derivational infixes, they are:

1. Infix $\{-$ in -$\}$ adjective

2. Infix $\{-$ um -$\}$ adjective

3. Derivational suffix

There is only Suffix $\{-$ an $\}$

1. Suffix $\{-$ an $\}+$ adjective Derivational Confixes

2. Confix $\{k a-a n\}+$ adjective

3. Confix $\{$ pa-an $\}+$ verb

4. Confix $\{$ maka - em $\}+$ adjective

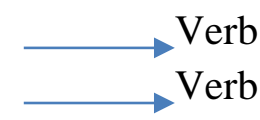

5. Confix $\{$ maka - em $\}+$ noun

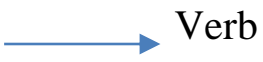

6. Confix $\{$ um-em $\}+$ adjective

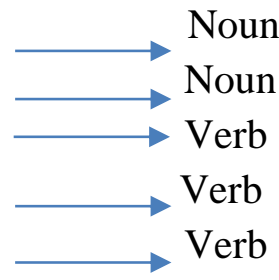

So derivational affixes in Tontemboan language is a morphological process because the addition or placement of affixes to a base of a word causes a change in the word class of the root word. 
Rinny Rorimpandey

This research is one of the efforts to develop the local languages, it is hoped it will give a contribution to the national culture so that it can be enjoyed by the coming generation. Another effort to perpetuate it is to teach it as a subject in schools and colleges. By learning local languages students know the social culture of Indonesia. Moreover, we might be able to know the linguistic differences and similarities.

The results of this writing are expected that it can be used as a reference for study and research, besides that it hopes to make it easier for teachers and parents to continue to preserve local languages and foster a love for local languages in children from an early age. Besides that, it can benefit the Minahasa community and preserve and teach their children to be proud to use the Tontemboan language. 


\section{BIBLIOGRAPHY}

Adhicahya, Theodorus. (2015). An Analysis of Idiom Translation of Ice Age Continental Drift Movie Subtitle. Yogyakarta: Sanata Dharma University. Google Scholar

Ahmed, Hussein Ali, \& Isma'eel, Huda Fadhil. (2011). Avoidance in Language Production. Adab AL Rafidayn, (60). Google Scholar

Azis, Azis. (2016). Pembinaan Bahasa Indonesia. Pena Indis. Google Scholar

Chaer, Abdul. (2003). Linguistik umum. Google Scholar

Effendy, Moh Hafid. (2011). Tinjauan Deskriptif Tentang Varian Bahasa Dialek Pamekasan. OKARA: Jurnal Bahasa Dan Sastra, 5(1). Google Scholar

Halikowski Smith, Stefan. (2016). Languages of subalternity and collaboration: Portuguese in English settlements across the Bay of Bengal, 1620-1800. International Journal of Maritime History, 28(2), 237-267. Google Scholar

Ingguoe, Leksi S. Y. (2015). Tata Bahasa Rote. Deepublish. Google Scholar

Kumayas, Tirza. (2021). Tontemboan Affixes Notes in Teaching English Tenses. International Journal of Applied Business and International Management, 6(1), 101-109. Google Scholar

Lieber, Rochelle. (2004). Morphology and lexical semantics (Vol. 104). Cambridge University Press. Google Scholar

Manaf, Ngusman Abdul, Juita, Novia, \& Sari, Ranti Permata. (2018). Shades of Meaning towards Mendengar Group Sinonym. International Conference on Language, Literature, and Education (ICLLE 2018), 333-338. Atlantis Press. Google Scholar

Maru, Mister Gidion. (2013). Jeremiad Frames in Reagan's Inaugural Addresses. Humaniora, 25(1), 25-37. Google Scholar

Maru, Mister Gidion, Nur, Sahril, \& Lengkoan, Fergina. (2020). Applying video for writing descriptive text in senior high school in the covid-19 pandemic transition. International Journal of Language Education, 4(3). Google Scholar

Mezrag, M. (2013). The importance of error analysis in the learners' writing skill: The case of first year English students at Biskra University (Dissertation submitted in partial fulfilment of the requirements for the Master Degree in Science of Language, Biskra University. Google Scholar

Mulyana, Deddy. (2000). Pengantar ilmu komunikasi. Bandung: Remaja Rosdakarya. Google Scholar 
Rinny Rorimpandey

Pamantung, RINA P. (n.d.). Noun Derivation of The Typical Minahasa Food and Beverage Names. e. Journal of Linguistics, 9(1), 21-28. Google Scholar

Payne, Mark, \& Almansour, Maram. (2014). Foreign language planning in Saudi Arabia: beyond English. Current Issues in Language Planning, 15(3), 327-342. Google Scholar

Siahaan, Jujur. (2012). Analisis Morfologis Adjektiva Bahasa Jerman. -, 1-10. Google Scholar

Sunardi, Sunardi. (2012). Morfologi Derivasional Dalam Bahasa Inggris. Lite: Jurnal Bahasa, Sastra, Dan Budaya, 8(1), 1-14. Google Scholar

Susanti, Alif N. U. R. Rochma. (2015). Analisis Kesalahan Gramatikal Bahasa Indonesia pada Karangan Mahasiswa Tiongkok di Malang. Jurnal Ilmiah Mahasiswa FIB, 3(1). Google Scholar

Tenda, Tirza Kartika. (2015). Sufiks Bahasa Inggris Dan Bahasa Tontemboan (Suatu Analisis Kontrastif). Jurnal Elektronik Fakultas Sastra Universitas Sam Ratulangi, 4(5). Google Scholar

Untung, Yuwono, Kushartanti, Kushartanti, \& Multamia, R. M. T. (2007). Pesona bahasa: langkah awal memahami linguistik. Gramedia Pustaka Utama. Google Scholar

Wibowo, G., \& Stockton, L. (2001). Microleakage of Class II composite restorations. American Journal of Dentistry, 14(3), 177-185. Google Scholar

Yule, George. (2016). The Study of Language 6th Edition. Cambridge University Press. Google Scholar

\section{Copyright holder:}

Rinny Rorimpandey (2021)

First publication right:

Syntax Literate: Jurnal Ilmiah Indonesia

This article is licensed under:

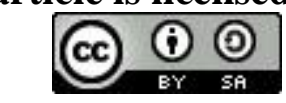

